\title{
TO DWELL AND TO REINHABIT: KIANA DAVENPORTS'S HOUSE OF MANY GODS AS BIOREGIONAL LITERATURE
}

\author{
Kristiawan Indriyanto \\ kristiawanindriyanto@gmail.com \\ Doctorate Student of American Studies \\ Universitas Gadjah Mada \\ Yogyakarta, Indonesia
}

\begin{abstract}
Environmental degradation has become a pivotal issue in Hawai'i nowadays. The policies of United States' government and military has shaped the Hawai'ian ecology. Through the process of ecological imperialism, started from the beginning of American colonialism, both the Hawailian's landscape and their connection with the environment is disrupted. Modern Hawai'ian ecology nowadays is a postcolonial ecology, which was, and still is molded by the American imperial power. As a product of colonialism, Hawai'ians' have become alienated with their ancestral traditions, especially regarding interrelation between human and non-human. Taking cues from Lawrence Buell's assertion that environmental crisis is a crisis of the imagination, modern Hawai'ian literature tries to reorient human-non human relationship from indigenous Hawai'ian epistemology. As seen in Kiana Davenport's the House of Many Gods, traditional Hawai'ian perspective is reimagined to reterritorialize Hawai'ians in their previous environmental outlook, before the arrival of the Americans. This study argues that by several bioregional concepts such as dwelling, and reinhabit, Kiana Davenport's the House of Many Gods can be stated as a bioregional literature.
\end{abstract}

Key Words: Bioregionalism, Hawaiian Literature, Environmental Imagination

\section{INTRODUCTION}

Environmental degradation had become a major concern in this modern era. As one of the leading countries inindustrial consumption and production, America plays an important role in causing this phenomenon. Huggan and Tiffin considers America as "a country that has actively and aggressively contributed to what many acknowledge to be the chronic endangerment of contemporary latecapitalist world"(2010:1). Excessive consumption, pollution, and waste as well neocolonial forms of globalization, militarism, and development (DeLoughrey and Handley, 2011:17) are several examples of American's impact upon the degrading environment. While American influences concerning the environment spread globally, this study specifically focuses in an area of intersection between American settlers and indigenous people in a colonial context, the American state of Hawai'i.

Viewed historically, the Hawai'ian ecology and landscape had and even is still shaped by the act of American imperialism. Since the arrival of the Whites (haole) started from the James Cook's expedition in the 1778, Hawai'i had undergone an ecological imperialism, a term coined by Alfred Crosby in his book Ecological Imperialism(1986). The interaction between the local/ indigenous people and the white settlers had been unequal, one-sided, and detrimental for the native Hawai'ians. While at first the Whites, especially America considered Hawai'i as their trading partner, they started to implement a more forcibly policy of colonialism to assert their authority. Started by taking Hawai'i as an American protectorate and a military coup which overthrow the last Queen of Hawai'i in 1893, American influence in Hawai'i had become even more entrenched. Any pretense of Hawai'ian sovereignty in the form of the Republic of Hawai'i is plainly abolished by the establishment of Hawai'i as the overseas territory of the United States (1898-1959) and the entry of Hawai'i as the $50^{\text {th }}$ state of U.S.A in 21 August 1959.

It can be stated that Hawai'ian ecology is a byproduct of colonialism, or postcolonial ecology. As stated by DeLoughrey and Handley (2011), 
postcolonial ecology refers to an ecology which was and is still shaped by the ongoing act of colonialism. American colonialism, especially in the form of ecological imperialism did not only result in "invasion, land-clearing, and destruction" (Handley and Tiffin, 2010:8), but it also happened in the form of "material and ideological imposition" (Worster, 1985). Through colonial education, the indigenous people are forbidden to learn their ancestral way of living and instead forced to adopt Western perspective regarding human and non-human relationship. This disruption of human ethical attitude toward the non-human goes side by side with the implementation of Western governmental system, a fact addressed by Said:

a changed ecology also introduced a changed political system that, in the eyes of the nationalist poet or visionary, seemed retrospectively to have alienated the people from their authentic traditions (1993:77). Hawai'ian writers particularly addresses environmental degradation as the result of American imperialism in their literature. The impact of American colonialism is their main issue, which makes them differ from mainland American environmentalist as a whole. While the environmentalism of the Whites takes forward the trope of pastoral, agriculture, and conservation as their subject matter, the "environmentalism of the poor" as coined by Nixon (2011) highlights different agenda. As the product of "spatial imagination made possible by the experience of place" (DeLoughrey and Handley, 2011:4), the Hawai'ian writers' imperial experience are fictionalized differently with other American environmentalist. As Hawai'ians have become alienated with their ancestral tradition due to American colonial intervention, Hawai'ian literature tries to "reimagine this displacement between people and place through poetics." (DeLoughrey and Handley, 2011:14)

Hawai'ian literature are advocative and politically oriented, as highlighted by the phenomena that many writers such as Hakunai Kay-Trask, Kiana Davenport, and
Louis-Ann Yamanakaare also noted as activists who wrote non-fictional works. Both their fiction and non-fictional work highlights strong anti-American critique and advocates a return to Hawai'ian sovereignty. Among those writers, this paper limits the scope of the analysis on Kiana Davenport's novel the House of Many Gods(2006). Reorientation of traditional Hawai'ian perspective, especially concerning human and nonhuman relationship is a pivotal theme in this novel. This issue is particularly reflected in the protagonist, Ana's journey from her ignorance of her own tradition into her outspoken embrace of Hawai'ian epistemology. Through Ana's struggle to reorient herself in her ancestral past, Davenport asserts how

literature performs an advocacy function both in relation to the real world(s) it inhabits and to the imaginary spaces it opens up for contemplation of how the real world might be transformed. (Huggan and Tiffin, 2011:1)

Davenport's effort to reorient Hawai'ians in their pre-colonial tradition also highlights many tenets of bioregional perspective. Through the reinterpretation of Hawai'ian environmental epistemology as a solution to modern environmental crisis, Davenport particularly addresses two bioregional tenets, dwelling and reinhabit. Hence, this paper argues that Davenport's fiction, especially the House of Many Gods can be categorized as part of bioregionalism as a whole. Further explanation of bioregionalism will be explained in the subsequent paragraphs.

\section{LITERATURE REVIEW}

This subsection focuses on reviewing several aspects regarding bioregionalism. Firstly, this paper briefly explores the origin of bioregionalism and its relation with other environmentalist movements. Going further into several bioregional concepts, there are two relevant terminologies: dwelling and reinhabit. These two terminologies are important to reimagine the relation between human and their surrounding in a 
bioregion. In this case, Davenport's House of Many Gods advocates a sense of environmental responsibility towards the readers.

Bioregionalism rises as an environmentalist movement in the United States since the 1970's. The advent of bioregionalism is linked with the increasing ecological awareness of the surrounding, or popularly known as 'environmental turn'. The publication of several books such as Rachel Carson's Silent Spring (1962) and Stewart Udall's the Quiet Crisis (1973) puts forward the detrimental impact of technology towards people and their surroundings. The rising recognition of environmental issue results in the birth of several environmental movements, in which bioregionalism is one of them.

While part of a wider environmental movement as a whole, bioregionalism has several distinctive characteristicscompared to the other environmentalist. Bioregionalism is more local in outlook compared to the regional and global environmental movements, furthermore bioregionalism focuses more on a particular bioregion. Bioregion is defined by Thayer, Jr as:

literary and etymologically a "life place"-a unique region definable by natural (rather than political) boundaries with a geographic, climatic, hydrological, and ecological character capable of supporting unique human communities. (2003:3)

Furthermore, bioregionalism particularly emphasizes a sense of belonging through close connection between people and their particular bioregion. In this way, bioregionalism criticizes modern society with their nomadic lifestyle and high mobility, and instead advocates "various forms of localism, theories and poetics of place and local belonging" (Heise,2008:4).In the increasing trend of deteritorialization of modernity - watching the same movies, reading the same books with other people all over the world-, bioregionalism instead aims to reterritorialize. Bioregionalism stresses that identity is connected with how human being interacts with their specific bioregion, a local ecosystem in which they are irrevocably imbedded (Aberley, 1993:13)In other word, bioregionalism asserts that human identity is linked with their specific bioregion.

Relating with how human interact with the world surrounding him/her, bioregionalism proposes several perspectives. As briefly mentioned before, dwelling and reinhabit are two key terminologies in bioregional point of view. Defining the term dwelling -to dwell-, it is related with how human should recognize their environment in the proximity. As mentioned by Sale (1985:42), to dwell means "to understand place, the immediate specific place where we live." Bioregionalism highlights the importance to live mindfully and deeply in place (Lynch and Glotfelty, 2012:4). Moving into the second concept, reinhabit, it is still closely related with dwelling. While recognizing that it is essential to elate with the natural world, it cannot be denied that modern environment has been disrupted and damaged by human's own actions. Reinhabitation as defined by Berg and Dasmann means not only to "learning to live in place....but doing so in an area that has been disrupted and injured through past exploitation" (1977:399). Hence, before we can dwell in a particular place, firstly restoration of the damaged environment is needed. The key tenet of reinhabitation as stated by Lynch and Glotfelty are

The idea is not simply to minimize harm to the environment, not simply to be able to sustain the current circumstances, but to find ways of living that repair the environmental harm caused by previous behavior. (2012:6)

\section{DISCUSSION}

Kiana Davenport's the House of Many Godsportrays the impact of American colonialism upon the indigenous Hawai'ian community. Taking site primarily in the island of O'ahu, especially around the Wai'anae Coast, Davenport vividly portrays the hardship faced by the indigenous Hawai'ian people in their living environment. 
Seaward, the Wai'anae Coast was untouched and magnificent, its beaches great strands of soft, white powder...Homestead youngsters raised on Welfare, their lives were circumcised by landless, poor education, drugs. Outsiders saw in them the criminal intent, the wish to self-destruct, not looking deeper where hunger for beauty lay. (Davenport, 2006:15)

The desolate landscape of the Wai'anae Coast is noted by the other Hawai'ians, especially city folks living in Honolulu who denoted this environment as "a junk kite" $(2006,21)$. The decaying and putrid living condition in this Coast is a remnant of the militarization of O'ahu island during the Second World War. "Quonset huts on either side of the road, left over from World War II, when the military occupied the land... where families lived in them now" are the silent witness of how American military especially U.S Navy contribute prominently towards the unhealthy living condition in Wai'nae Coast.

The degrading environment of O'ahu is the birthplace of the protagonist of this novel, Ana, Anahola is her full name which is also her mother's name. Her mother's abandonment of her shapes Ana's early childhood. Although she is raised in a loving nuclear family, her lack of maternal love is detrimental for her personality. She turns out into a lonely and even alienated person.

"She's lonely", Pua said

Why, lonely? She got a house full of folks who love her

She doesn't have a mother, not the same (Davenport, 2006:23)

The increasing numbers of newborn infants reduce Ana's importance in her family. "Less and less the center of attention, Ana become a watcher" (Davenport, 2006:46). She silently participates in any family activities, although her heart is not fully devoted toward it. In time, she even considers her island as a cage, which led to her running away into mainland America, California. Her journey is rushed, as if she desperately tries to escape the life without happiness in Hawai'i. After boarding the ship Lurline out of Honolulu, bound for San Francisco "she tried to reinvent herself" (Davenport, 2006:30), finding her new identity in urban environment of California.

In Ana's new life in San Francisco,she finds out that living in the metropolis is even harsher than her childhood in Wai'nae Coast. To survive, she must do many odd-jobs such as washing dishes, waitressed, and selling dim sum. It is her interaction with an American scientist, Max Mc Cormickwhich begins to recollect Ana in her ancestral Hawai'ian terminology. Recognizing Ana's innate intelligence, Max "sends Ana to college to achieve her degree in medical science, biochemistry" (Davenport, 2006:36). She considers her new life as a blessing, especially compared to "the grueling first year in Chinatown." More importantly, through her close relationship with Max, she begins to recognize the inherent virtue of traditional Hawai'ian epistemology.

A pivotal occurrence which reorient Ana in her indigenous environmental perspective is her return voyage to Hawai'i. While at first she is reluctant in doing so, afraid that "the island will take her hostage again" (Davenport, 2006:36), she realizes that her homecoming helps her to reconnect towards the world surrounding him. Previously confined in the skyscrapers in the metropolis area, returning back towards her native island holds her firmly in the nature's embrace. As narrated in the novel,

she hears the blending of Pidgin and Hawaiian Mother tongue that in the mouth of soft-voiced elders become intrinsically poetics. One night, hearing the wounded music of the sea, she runs barefoot to the beach and dives into moon-shot waves. She feels the harmony of things, the bliss of letting go. (Davenport,2006:36)

From the aforementioned passage, it can be noted how Anna begins to reorient -or to dwell- in her local Hawai'ian environment. Furthermore,through her 
interaction with the family she left behind, Ana firmly reestablishes her Hawaiian heritage. One notable event which illustrate Ana's recollection is the birth of Rosie's -her cousin- child, in which Ana helps deliver the baby as a midwife. Since the pregnancy until the date of birth, her family employs traditional Hawaiian culture prominently, such as the sea bath. This event refers on how the pregnant mother Rosie- stands still in calm water, moving her stomach back and forth to ease the birthing process (Davenport, 2006:63). Moreover, Rosie is encouraged to eat certain seafood such as shrimp and squid so that the child would be loving and clinging. (Davenport, 2006:63). Remembering all the ceremonies she undergoes during Rosie's pregnancy, Ana remarks how

reflecting on the long, exhausting hours of that day -the birthing, and praying, the taking and sharing of pain, and love-in that moment Ana saw how rich they were, how thick their blood coursing the generations. It was a family, that did not keep up with time, but rather allowed time to pause, stand still, and catch its breath....In those moment she understood that these people, and this house, would always be her solace. Her language. And her place. (Davenport, 2006:71)

Anna's experiences in traditional Hawai'ian customs, things she previously neglected during her early childhood enables her to reorient herself in Hawaiian tradition. She recognizes how her family still abide towards established custom and tradition regarding pregnancy and birthing method which had been going on for centuries. As stated in the preceding quotation, this is the moment where Ana realizes that her family, her neighborhood, and the Hawaiians as a whole is where she really belongs, unlike how alienated she experiences in the mainland America. Through her reorientation in her heritage, she also understands her position, especially in what way she can contributes toward the wellbeing of the Hawai'ians, the people who are still marginalized by the American government. Since the moment she helps deliver Rosie's baby, Ana recognizes how she possesses a gift in medical field, to heal and contributes in the process of recovery. Although she is trained as a nurse, Ana does not want only to help people with their sickness, she also intends to repair the damaged Hawai'ian landscape through the bioregional concept of reinhabitation.

It can be stated that from this point forwards, Ana moves from the concept of dwelling into reinhabitation. While previously Ana only tries to reinvent herself in her tradition -, now she plays a more active role in reimagining Hawai'ian local tradition as the solution toward environmental crisis faced in her island. Her first action is to teach the knowledge of her Hawaiian past to the closest person to her, Max. Ana's interaction with Max reveals much about the ancestral tradition of the Hawaiians, as narrated by Ana:

now I will tell you that some folks say much of the ancient life and history of the Polynesians who discovered this island and lived here for two thousand years has been forgotten....But a'ole loa! Absolutely not. Our history is never forgotten. Only hidden.... Placenames remain, and with them the name of the chiefs and chiefesses, gods and demigos.

Ana asserts the importance of the Hawaiians to remember their past, their lost histories forgotten through the long process of colonialism. Remembrance is needed to highlight their close connection with the world around them. One passage from the text aptly illustrates the Hawaiian's environmental concept: "like people the world over, we believe that the coming of the sun brings mana, life force to the earth each day. With mana, comes healing, growth, life itself" (Davenport, 2006:118).

Healing the damaged environment is one major tenet of bioregionalism especially the concept of reinhabitation. Ana especially criticizes how the American Navy uses Makua Valley as a site for 
weapon testing which resulted in the once beautiful valley turned into a "no-man's land" (Davenport, 2006: 52). Yet though the condition there is harsh and inhumane, several Hawaiians resides here as a temporary residence, a pu'uhonua or refugee. "People healed, and stayed, sweeping their beaches clean of garbage. They become once again kahu o ka' aina, stewards of the land. "(Davenport, 2006:135) Hawaiians resist American's degrading effect on the environment and they emphasize how even though the situation is putrid, they still emphasize the importance of respecting the ecology, keeping it clean from trash. This act of resistance, peacefully instead of open conflict is the proper way to restore the environment. "To win over the valley was not by trying to defeat the military, but to win them over to the people's side" (Davenport, 2006:340). By proclaiming the Hawaiian's closeness to the aina (land), the Hawaiians are able to win petition from the United Nation which review the improper use of military force in Makua Valley. Hence, Davenport's the House of Many Gods ends in an optimistic tone, how the earth is able to heal itself once again, as exemplifies here:

The bombs are silent at Makua. For several years there has been peace. Nature slowly begins to heal itself. In the soil, roots take hold, seeds swell and lengthen. Folks say they are the seeds of freedom, and that it time winds will blow those seeds and germinate the land. (Davenport, 2006:356)

\section{CONCLUSION}

It can be summarized that the House of Many Gods is a bioregional novel with the emphasis of two concepts, to dwell and to reinhabit. As symbolized by Ana's reorientation in her native Hawaiian's outlook, the tenet of dwelling manifests in the text. While at first Ana is alienated from her indigenous side, her experiences living again in a rich vein of Hawaiian culture leads her to embrace her tradition once again. By recognizing that Hawaiian is part of herself, she becomes more vocal in advocating reinhabitation to repair the degraded Hawaiian environment. By emphasizing local Hawaiian's tradition of living closely with the earth, becoming the steward of the land kahu o ka' aina, the Hawaiians asserts that American's military allocation in Makua Valley is disruptive toward the local ecosystem. In the end, the Hawaiians especially who live in Wai'nae Coast, especially Makua Valley resident managed to restore their surroundings.

\section{REFERENCES}

Aberley, D (1993) Boundaries of Home: Mapping for Local Empowerment. Gabriola Island, B.C.: New Catalyst,

Berg, P \& Dasmann, R. (1977) “Reinhabiting California.” The Ecologist 7.10: 399-401

Buell, L. (1995) The Environmental Imagination: Thoreau, Nature Writing and the Formation of American Culture. Cambridge: MA Harvard University Press

Crosby, A. W. (1986) Ecological Imperialism: The Biological Expansion of Europe, 900-1900. Cambridge: Cambridge University Press

Davenport, K. (2006) House of Many Gods. New York : Random House Inc

DeLoughrey, E \& Handley, G.B (2011) Postcolonial Ecologies : Literature of the Environment Oxford:Oxford University Press

Heise, U. K. (2008) "Ecocriticism and the Transnational Turn in American Studies." American Literary History. Vol. 20 (1-2), pp. 381-404 
Huggan, G \&Tiffin, H. (2010). Postcolonial Ecocriticism: Literature, Animals, Environments. New York: Routledge.

Lych, T \& Glotfelty, C (2012) The Bioregional Imagination : Literature, Ecology and Place. Athens : University of Georgia Press

Nixon, R. (2011). Slow Violence and the Environmentalism of the Poor. Harvard: Harvard University Press

Sale, K. (1985) Dwellers in the Land: The Bioregional Vision. Athens: University of Georgia Press.

Said, E. (1993) Culture and Imperialism. New York : Vintage Books

Worster, D. (1985) Nature's Economy: A History of Ecological Ideas, Cambridge: Cambridge University Press 